$\mathbb{T}$ periodica polytechnica

\author{
Civil Engineering \\ $55 / 2(2011) 169 \sqrt{176}$ \\ doi: 10.3311/pp.ci.2011-2.09 \\ web: http://www.pp.bme.hu/ci \\ (c) Periodica Polytechnica 2011
}

RESEARCH ARTICLE

\section{Traffic analysis of two-lane highways}

István Fi / János Galuska

Received 2010-11-08, revised 2010-12-13, accepted 2011-06-13

\begin{abstract}
The analysis of huge rows of traffic data collected loop detectors we can get a lot of information about the traffic conditions of different highway sections. These equipments are able to measure the vehicle speed, following time and of course the traffic volume in different vehicle types. Such a measurement types are the best to choose those sections where catch the maximum value of vehicle traffic. Comparing our regulations to the HCM two basic differences can be noticed. Instead of A - E HCM LOS only two levels are used in Hungarian regulations. The tolerable $\left(F_{m}\right)$ is the design level. The eligible $\left(F_{e}\right)$ is the so called intervention level (when the capacity can only be risen with an intervention). The eligible capacity (2000 pcph) is significantly lower than the capacity of HCM (3200 pcph) recommendation.

On the base of our results can be recommended to use the 3200 pcph HCM 2000 recommendation as the possible traffic volume also in Hungary. By these about $30 \%$ higher capacity values the network development can be planned more rational.
\end{abstract}

\section{Keywords}

traffic data analysis $\cdot$ two-lane highway capacity $\cdot A-F$ level of services

\section{Acknowledgement}

This work is connected to the scientific program of the "Development of quality-oriented and harmonized $R+D+I$ strategy and functional model at BME" project. This project is supported by the New Széchenyi Plan (Project ID: TÁMOP-4.2.1/B09/1/KMR-2010-0002).

Special thanks to Péter Bocz and Gabriella Devecseri for their help in the completion of measurements.

\section{István Fi}

Department of Highway and Railway Engineering, BME, H-1111 Budapest, Múegyetem rkp 3, Hungary

e-mail: fi@uvt.bme.hu

\section{János Galuska}

Lánchíd Holding closed Ltd, H-1011, Budapest, Fő u. 1., Hungary

e-mail: galuska@enternet.hu

\section{Characterization of traffic conditions (Theoretical bases)}

Traffic volume, including demand volume (for a peak 15-min period within the hour of interest), speed and density are the main three parameters are used for the characterization of traffic conditions. Some other variables related to demand volume like headway, and spacing are also used for the characterization of continuous flows. In this study road sections with unsignalized intersections and continuous traffic streams (except special cases of congestion) are examined.

Number of passing vehicles of a cross section depends on the following three parameters:

1 traffic volume, and the volume for a peak 15-min period within the hour of interest,

2 speed,

3 density.

Spacing and headway can be calculated directly from these variables.

Traffic volume and volume of a peak 15-min period determines the possible number of vehicles passing one cross section of the road during a specified interval of time. The exact definition is the following:

1 Traffic volume: number of vehicles passing one cross section of the road during a predetermined interval of time. The measurement can last from a shorter period of time to an hour, a day or a year. In the Hungarian practice usually the peakhour traffic volume, the so called standard hourly traffic (pcph, vph) is in use.

2 Volume for a peak 15-min period: hourly demand volumes of a cross section can be calculated from this volume. This parameter widely used by Highway Capacity Manual 11 (HCM) in the world.

Speed (or its reciprocate, the travel time) is an important parameter of the road service quality. The level of service (LOS)

\footnotetext{
1 Publication of the Transportation Research Board (TRB) in the United States, latest edition HCM 2000 [1].
} 
of different constructions can be determined by this parameter too.

According to the well known definition speed is the distance travelled during a period of time, expressed in $\mathrm{km} / \mathrm{h}$ unit. To characterize different traffic flows various representative speeds are used, because speeds of individual vehicles are quite variables.

In traffic analysis in most of the cases average travel speed is used. This value can be calculated easily from the individual vehicle speeds. Average travel speed can be calculated by dividing the length of the measured section of the road with the average travel time of passing vehicles. Thus, if the travel times of $n$ pieces of vehicles one after the other are $t_{1}, t_{2}, \ldots, t_{n}$ on a road section with a length of $L$ than the average travel speed can be computed using the following equation:

$$
S=\frac{L}{\sum_{i=1}^{n} t_{i} / n}=\frac{n L}{\sum_{i=1}^{n} t_{i}}
$$

where:

$S$ average travel speed $[\mathrm{km} / \mathrm{h}]$,

$L$ length of the road section [m],

$t_{i}$ travel time of the given vehicle on the measured road section [h] and

$n$ number of measured travel times.

Travel times of the calculation include different delays too. They mean the total travel time of the travelled distance.

For the characterization of traffic flow other different speeds could be used like:

Average travel speed - Determination is based on the measured travel speeds of vehicles along a reasonable length of road. It is calculated by dividing the length of the road with the average travel speeds of passing vehicles. Travel time means the time when vehicles are in move. In case of continuous traffic flow (on highways) usually the average travel speeds and the average running speeds are equal with each other (in case of no concession).

Space mean speed - It is calculated by dividing the length of a road section with the travel speed of its passing traffic. Space mean speed is always less than time mean speed, but the difference decreases in case of rising speed.

Time mean speed - The average of passing vehicle speeds is measured at one given point of the road. Often it is called as ,average spot speed". For the capacity analysis the necessary speed measurements can be done the easiest by field measurements. A road section in case of continuous traffic flow (a stable flow) there is no use to have the observed section longer than 100 meters. Radiolocation or other similar instrument could be used to collect data from the actual speed of vehicles. The average of the measured speeds gives the time mean speed.
Density is defined as the number of vehicles on a given length of the road in a given minute. Density is averaged by the time. It is expressed in veh/ $\mathrm{km}$ unit.

To measure density on site is quite difficult, because it would need such point of view on the road from where a long section of the road can be observed. But it can be calculated from the average travel speed, and the traffic volume which are easier to be measured:

$$
D=v / S
$$

where:

$v$ traffic volume [veh/h],

$S$ average travel speed $[\mathrm{km} / \mathrm{h}]$ and,

$D$ density $[\mathrm{veh} / \mathrm{km}]$.

So as density characterizes the quality of the traffic service it became a very important parameter of roads (in case of continuous traffic flow). It describes the distance between vehicles and it gives an image from possible free moving.

Sometimes instead of density road reservation is also used, because it is easier to be measured when traffic control systems are located on the road. Spatial reservation is that length of the road where it is reserved by vehicles. Temporal reservation means the length of passing time spent by vehicles at a given cross section during a predefined interval of time.

Spacing is the distance between vehicles following each other. It is measured between the first bumpers of the vehicles. Headway means the time passing between two following vehicles enter a given cross section with their first bumpers.

These parameters are called ,microscopic” parameters, because they describe individual vehicle pairs of the traffic flow. But spacing and headway distribution have relation with such „macroscopic” parameters of the traffic stream like speed, density, and traffic volume for a peak 15-min period.

Headway is used for predicting the percent time delay on twolane main roads. Percent time delay could be estimated with the percentage of vehicle headways less or equal to $5 \mathrm{sec}$.

\subsection{Mathematical relationships}

The average headway has a direct relation with the traffic density:

density $[\mathrm{veh} / \mathrm{km}]=1000 /$ following-distance $[\mathrm{m} / \mathrm{veh}]$

Typical spacing in traffic flow and headway depend on the speed:

headway $[\mathrm{s} / \mathrm{veh}]=$ spacing $[\mathrm{m} / \mathrm{veh}] /$ speed $[\mathrm{m} / \mathrm{s}]$

This relation stands also between individual vehicle pairs. In this case the speed of the second car should be written into the formula. The traffic volume depends on the average time-spentfollowing of the traffic flow:

traffic volume $[\mathrm{veh} / \mathrm{h}]=3600[\mathrm{~s} / \mathrm{h}] /$ headway $[\mathrm{s} / \mathrm{veh}]$

Fig. 11 demonstrates graphically these well known relations and it gives theoretical background for the capacity analysis of 
roads managing continuous traffic flows. Although other more complicated theories exist for the analysis of traffic movements, this linear speed-density relation gives an easy way to understand the main features and speak about the subject.

The real shape of these functions depends on the existing road and traffic conditions and the chosen length of the section which was used during the speed measurement.

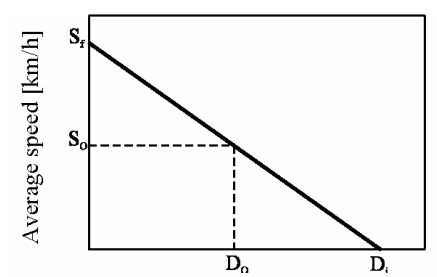

Density $[\mathrm{pc} / \mathrm{km} / \mathrm{ln}]$

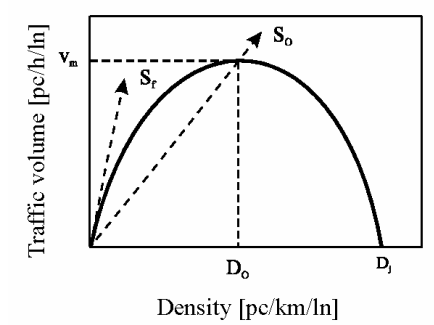

Fig. 1. Basic speed, density, traffic volume relations of continuous traffic flows

It should be noted in relation with the diagrams of Fig. 1 1 that zero traffic volume occurs in two extreme cases:

When there is no car on the road, the density and the traffic volume is equal with zero. The chosen speed is theoretically (it is supposed that the driver chooses high speed in this case). This speed is signed with $S_{f}$ in the diagrams.

When the density reaches such high value where all vehicles have to stop (speed becomes zero), the traffic volume becomes zero, because the movement stops. The density when all the movement stops is the so called congestion density signed with $D_{j}$ in the figure.

Between these two extreme cases traffic flow dynamics has a maximum. Speed, and traffic volume rises from zero. When the number of vehicles becomes relevant speed starts to decrease, because vehicles have already an effect to each other. This speed loss is irrelevant near low, and middle density and traffic volume. When the speed continues to rise, when traffic volume gets close to reach the maximum capacity the speed starts to decrease significantly. We reach the capacity when the product of density and speed results the maximum traffic volume. Optimal speed $S_{o}$ (often called as critical speed), optimal density $D_{o}$ (sometimes called as critical density) and maximum traffic volume are the parameters which are used for the characterization.

Adapting straights from the starting point of the diagrams to any point of the curve the gradient of the straight would mean the speed. Similarly a straight in the density-traffic volume diagram also means the speed.

As it can be seen in Fig. 1, any traffic volume which is not equal with the capacity can arise near two different conditions. It can arise in case of high speed and low density and on the other hand near high density and low speed. The high density-low speed sections of the diagrams mean the impeded traffic flow.

After consideration of the theoretical description follows the chosen subject, the traffic flow analysis of two-lane roads.

\subsection{Hungarian regulations of the capacity in case of two- lane roads}

The capacity of two-lane roads is regulated by the Közutak Tervezése (Highway Design Standard) [2]. According to the previous [3] and the present regulation [2] the allowed maximum traffic volumes are the followings (Table 1 ):

Tab. 1. The capacity of two-lane rural roads according to the recent and the previous standards

\begin{tabular}{lcc}
\hline Public roads & Eligible $\mathbf{F}_{m}$ & Tolerable $\mathbf{F}_{e}$ \\
\cline { 2 - 3 } & Allowed traffic volume belonging to LOS \\
pcph & \\
\hline $\begin{array}{l}\text { Two-lane roads (two } \\
\text { direction) } \\
\text { (MSZ-07-3713-86 } \\
\text { Közutak Tervezése } \\
\text { 1986.) }\end{array}$ & 900 & 1400 \\
\hline $\begin{array}{l}\text { Two-lane roads (in } \\
\text { two direction together) } \\
\text { (Közutak Tervezése } \\
\text { ÚT 2-1.201:2008.) }\end{array}$ & & \\
\hline
\end{tabular}

The previous regulation contained adjustment factors related to lane width $(3,25: \times 0,9 ; 3,0: \times 0,8 ; 2,75: \times 0,65)$ and other features (the lack of overtaking sight distance or climbing lane or not enough lateral clearance) which reduced the value of the capacity. However it did not define precise methodology for the use of these factors.

The current regulation does not contain reducing factors but it fixes the minimum sizes of the cross section elements and the minimum value of lateral clearance in the direction of travel in relation with design speeds.

\section{New Hungarian measurements on two-lane roads}

Points of measurements are seen in Table 2 We tried to observe rural road sections of the Hungarian network, where the traffic was high enough to measure capacity values.

Three types of speed control units were installed on the road sections:

$A D R$

Raktel

QLD

The ADR system observes the length, the speed and the lane of each passing vehicle at the cross section and it categorises them into a predefined vehicle category. It collects these data in a readable text file with the exact minute of passing (at the second). 
Tab. 2. Observed speed control units

\begin{tabular}{ccccc}
\hline $\begin{array}{c}\text { Sign of } \\
\text { Detector }\end{array}$ & $\begin{array}{c}\text { Road } \\
\text { Number }\end{array}$ & Location & System & $\begin{array}{c}\text { Number of } \\
\text { Measured } \\
\text { Hours }\end{array}$ \\
\hline 1060 & 1 & Biatorbágy & QLD & 3428 \\
\hline 1201 & 7 & Lepsény & Raktel & 4519 \\
\hline 1247 & 1 & Vértesszőlős & QLD & 2232 \\
\hline 3247 & 83 & Győr & QLD & 3430 \\
\hline 3987 & 1 & Györ & QLD & 3428 \\
\hline 5893 & 35 & Debrecen & QLD & 1035 \\
\hline 1001 & 2 & Budapest & ADR & 827 \\
\hline
\end{tabular}

The Raktel system counts the number of vehicles in each lane during a predefined period of time ( 6 minutes $\div 60$ minutes) and classifies them into predefined speed categories. As a result it gives the number of passing vehicles. It counts heavy vehicles separately from the speed categories, but it gives the summed speed of vehicles in $\mathrm{km} / \mathrm{h}$. The speed of personal cars can only be estimated because of the categories.

The QLD system gather data of a 60 minutes interval of time. The data (mean speed and number of vehicles/in vehicle categories/) comes out from a data base.

After collecting the data we divided the vehicles into two categories: „car” and „non-car” categories. The reason of this one hand was the precision of the speed control units, the other hand the easier data handling. For the heavy vehicle factor 1,5 values (the heavy vehicle equivalent factor of HCM in case of plan site) was set out. We analysed data only between 5 am and 7 pm. The observed period can be seen in Table 2. We have made the analysis in each case separately into both directions.

During the measured hours the hourly traffic volume is [pcph] $=1,1 \times$ (number of cars $+1,5 \times$ number of non cars). The 1,1 value is the ratio of the peak hour and 15-min peak period according to the followings.

The American HCM manual [1] uses peak 15-min period instead of the Hungarian peak hour. That means instead of the traffic of the busiest hour four times the traffic of 15-min period with the highest traffic is taken into consideration. So the short term peak values can point out, they do not ,mash” that easily as it happens in case of peak hour.

We can define the ratio of the peak hour and the quardrupled of peak 15-min period in two ways:

In the first case we create the ratio from the busiest 50 hours. We choose the busiest 50 hours and we define traffics for the peak 15-min period in each hour, than we take this value four times. According to this we receive 50 ratios. The ratio is the quotient of the peak hour traffic and the qurdrupled peak 15 period traffic. The average of the 50 ratios gives the demanded result.
In the second case we create the ratio similarly to the previous case, but we use the busiest measured hour (peak hour). For the calculation we take four times the traffic of the peak 15-min period of this peak hour.

In Table 3 the peak 15-min period factors can be found

Representing the measured values in traffic volume [pcph] mean speed $[\mathrm{km} / \mathrm{h}]$ diagram we receive a ,spotcloud". A linear trendline can suit on the „spotcloud”. The trendline is a monotonic regressive line with changeable decreasing steps. The size of the steps depends on the local circumstances and the maximum traffic volume. In Table 4 the maximum traffic volumes of measured cross sections and the equations of the tangent lines for each road sections can be seen. Fig. 2 shows the trendlines because of comparison.

We have met with overloaded capacity only at the observed $\mathrm{N}^{\circ}$ 1060 ( ${ }^{\circ} 1$ mainroad, Biatorbágy) point Fig. 3.4 We received ,a turning back" curve here, which means that the capacity can not grow after this point. At the same time $\mathrm{N}^{\circ} 1060$ detector has produced the highest traffic volume. According to the diagrams by the rising traffic volume the speed of the right lane decreased more quickly. The reason of this should be sought in road elevation.

The free flow speed on $\mathrm{N}^{\circ} 1201$ detector was rather low. The average did not reach either $70 \mathrm{~km} / \mathrm{h}$. Here the $90 \%$ of the traffic volume left under $400 \mathrm{pcph}$, only in very special cases run above this.

On $\mathrm{N}^{\circ} 1247$ detector the maximum of the traffic set around $1000 \mathrm{pcph}$. The gradients of the regression lines were small, and the free flow speed was low. It should be taken into consideration that the observation happened in urban area.

The free flow speed was set around $74 \mathrm{~km} / \mathrm{h}$ on $\mathrm{N}^{\circ} 3247$ detector and it decreased with a medium gradient, like the regression of $\mathrm{N}^{\circ} 3987$ detector, where the free flow speed was a little bit higher $(83-85 \mathrm{~km} / \mathrm{h})$.

The free flow speed set around $70 \mathrm{~km} / \mathrm{h}$ on $\mathrm{N}^{\circ} 5893$ detector. The rising traffic volume caused more intensive decrease in speed values.

The behaviour of the two directions was different on $\mathrm{N}^{\circ} 1001$ detector. It could be answered with the location of the observation point, because it was located to the end of Budapest on $\mathrm{N}^{\circ} 2$ main road. In case of outward traffic the increasing traffic volume had less effect on speed, than inward traffic. Free way speed was almost equal with each other, it set out around $68-69 \mathrm{~km} / \mathrm{h}$. It should be noted that the observation point was located in a site curve. In the past the Biztonságkutató Mérnökiroda (Safety Research Office) had also made some measurements from this point. To compare recent speeds with the previous speeds it can be find out that the free flow speed becomes lower. 
Tab. 3. Values of peak 15-min factors

\begin{tabular}{|c|c|c|c|c|c|}
\hline Highway & Junction & Direction & Type of Lane & $\begin{array}{l}\text { Peak 15-min period Factor } \\
\text { (50 hours) }\end{array}$ & $\begin{array}{c}\text { Peak 15-min period Factor } \\
\text { (peak hour) }\end{array}$ \\
\hline Mo & M0-M5 & right & freeway & 0,92 & 0,84 \\
\hline Mo & M0-M5 & left & freeway & 0,94 & 0,88 \\
\hline M0 & M0-M1 & left & freeway & 0,84 & 0,75 \\
\hline MO & M0-M1 & right & freeway & 0,87 & 0,87 \\
\hline M0 & M0-M7 & left & freeway & 0,93 & 0,83 \\
\hline MO & M0-M7 & left & overtaking & 0,81 & 0,63 \\
\hline MO & M0-M7 & right & freeway & 0,93 & 0,90 \\
\hline MO & M0-M7 & right & overtaking & 0,87 & 0,70 \\
\hline Mo & Mo-Szm & left & freeway & 0,95 & 0,74 \\
\hline Mo & Mo-Szm & left & overtaking & 0,87 & 0,88 \\
\hline MO & M0-Szm & right & freeway & 0,95 & 0,93 \\
\hline MO & Mo-Szm & right & overtaking & 0,89 & 0,98 \\
\hline M1 & M0-M1 & right & freeway & 0,94 & 0,79 \\
\hline M1 & M0-M1 & right & overtaking & 0,88 & 0,75 \\
\hline M5 & M0-M5 & left & overtaking & 0,93 & 0,94 \\
\hline M5 & M0-M5 & left & freeway & 0,95 & 0,79 \\
\hline M5 & M0-M5 & right & overtaking & 0,89 & 0,74 \\
\hline M5 & M0-M5 & right & freeway & 0,92 & 0,84 \\
\hline M7 & M0-M7 & left & freeway & 0,88 & 0,80 \\
\hline M7 & M0-M7 & left & overtaking & 0,93 & 0,88 \\
\hline M7 & M0-M7 & right & freeway & 0,94 & 0,96 \\
\hline \multirow[t]{28}{*}{ M7 } & M0-M7 & right & overtaking & 0,92 & 0,94 \\
\hline & M0-M5 & right & off-ramp & 0,90 & 0,75 \\
\hline & M0-M7 & left & on-ramp & 0,84 & 0,60 \\
\hline & M0-M7 & right & on-ramp & 0,90 & 0,79 \\
\hline & M0-M7 & right & on-ramp & 0,89 & 0,78 \\
\hline & M0-Szm & left & off-ramp & 0,68 & 0,43 \\
\hline & M0-Szm & right & on-ramp & 0,91 & 0,85 \\
\hline & Mo-Szm & right & on-ramp & 0,78 & 0,72 \\
\hline & M0-M1 & left & on-ramp & 0,80 & 0,63 \\
\hline & M0-M1 & right & on-ramp & 0,89 & 0,88 \\
\hline & M0-M1 & right & on-ramp & 0,73 & 0,85 \\
\hline & M0-M5 & right & off-ramp & 0,93 & 0,93 \\
\hline & M0-M7 & left & off-ramp & 0,87 & 0,76 \\
\hline & M0-M7 & right & on-ramp & 0,88 & 0,93 \\
\hline & M0-M1 & left & off-ramp & 0,77 & 0,95 \\
\hline & M0-M7 & left & off-ramp & 0,89 & 0,82 \\
\hline & M0-M7 & left & off-ramp & 0,86 & 0,86 \\
\hline & M0-M1 & left & on-ramp & 0,73 & 0,78 \\
\hline & M0-M1 & right & on-ramp & 0,78 & 0,69 \\
\hline & M0-M1 & right & off-ramp & 0,78 & 0,71 \\
\hline & M0-M7 & right & off-ramp & 0,78 & 0,67 \\
\hline & Mo-Szm & left & on-ramp & 0,92 & 0,87 \\
\hline & Mo-Szm & right & off-ramp & 0,88 & 0,90 \\
\hline & M0-M7 & left & on-ramp & 0,85 & 0,62 \\
\hline & M0-M7 & right & off-ramp & 0,84 & 0,57 \\
\hline & M0-Szm & left & off-ramp & 0,87 & 0,73 \\
\hline & M0-Szm & right & turning & 0,72 & 0,70 \\
\hline & M0-Szm & right & off-ramp & 0,76 & 0,93 \\
\hline
\end{tabular}


Tab. 4. Traffic flows of observed cross sections

\begin{tabular}{|c|c|c|}
\hline $\begin{array}{l}\text { Sign of Detector } \\
\text { (Number of Roads, } \\
\text { Location) }\end{array}$ & $\begin{array}{l}\text { Max. Traffic Volume } \\
(\mathrm{pc} / \mathrm{h})\end{array}$ & $\begin{array}{l}\text { Equation of } \\
\text { Trendline }\end{array}$ \\
\hline $\begin{array}{c}1060-N^{\circ} 1 \text {. main road } \\
\text { right (Biatorbágy) }\end{array}$ & 1657 & $S=-0,0197 \times F+76,6$ \\
\hline $\begin{array}{c}1060-N^{\circ} 1 \text {. main road } \\
\text { left (Biatorbágy) }\end{array}$ & 1957 & $S=-0,0100 \times F+67,5$ \\
\hline $\begin{array}{c}1201-N^{\circ} 7 \text {. main road } \\
\text { right (Lepsény) }\end{array}$ & 1271 & $S=-0,0110 \times F+68,5$ \\
\hline $\begin{array}{c}1201-N^{\circ} 7 \text {. main road } \\
\text { left (Lepsény) }\end{array}$ & 1190 & $S=-0,0187 \times F+66,1$ \\
\hline $\begin{array}{l}1247-N^{\circ} 1 \text {. main road } \\
\text { right (Vértesszőlős) }\end{array}$ & 1054 & $S=-0,0062 \times F+43,9$ \\
\hline $\begin{array}{c}1247 \text { - N¹. main road } \\
\text { left (Vértesszőlős) }\end{array}$ & 983 & $S=-0,0080 \times F+53,3$ \\
\hline $\begin{array}{l}3247 \text { - N83. main } \\
\text { road right (Győr) }\end{array}$ & 696 & $S=-0,0153 \times F+74,5$ \\
\hline $\begin{array}{c}3247 \text { - N83. main } \\
\text { road left (Győr) }\end{array}$ & 989 & $S=-0,0142 \times F+74,9$ \\
\hline $\begin{array}{c}3987-\mathrm{N}^{\circ} 1 \text {. main road } \\
\text { right (Győr) }\end{array}$ & 1168 & $S=-0,0135 \times F+82,1$ \\
\hline $\begin{array}{c}3987-N^{\circ} 1 \text {. main road } \\
\text { left (Győr) }\end{array}$ & 1326 & $S=-0,0185 \times F+85,8$ \\
\hline $\begin{array}{l}5893 \text { - N`35. main } \\
\text { road right (Debrecen) }\end{array}$ & 702 & $S=-0,0225 \times F+71,1$ \\
\hline $\begin{array}{l}5893-N^{`} 35 . \text { main } \\
\text { road left (Debrecen) }\end{array}$ & 961 & $S=-0,0191 \times F+74,4$ \\
\hline $\begin{array}{c}1001-N^{\circ} 2 \text {. main road } \\
\text { right (Bp. end) }\end{array}$ & 819 & $S=-0,0061 \times F+67,8$ \\
\hline $\begin{array}{l}1001-\mathrm{N}^{\circ} 2 \text {. main road } \\
\text { left (Bp. end) }\end{array}$ & 1143 & $S=-0,0112 x F+69,6$ \\
\hline
\end{tabular}

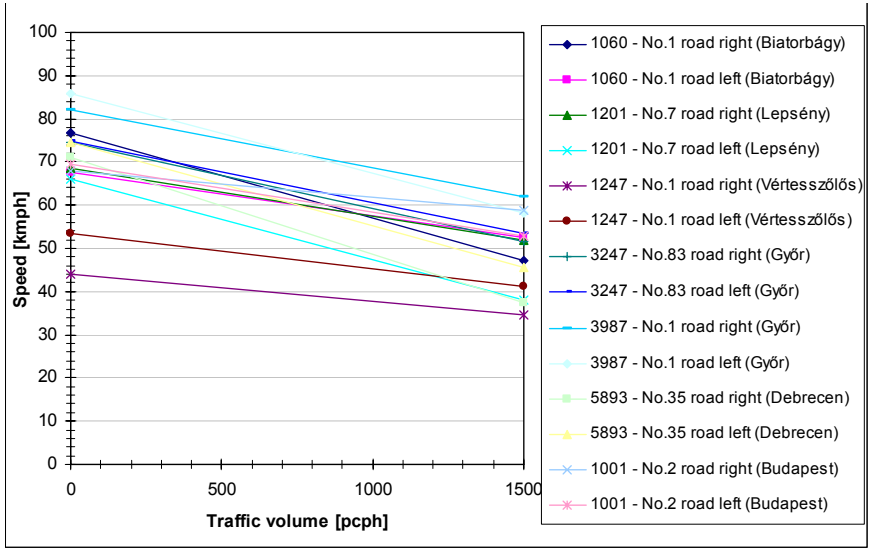

Fig. 2. The regression straights of the observed two-lane roads
1060 - No.1 main road right lane (Biatorbágy)

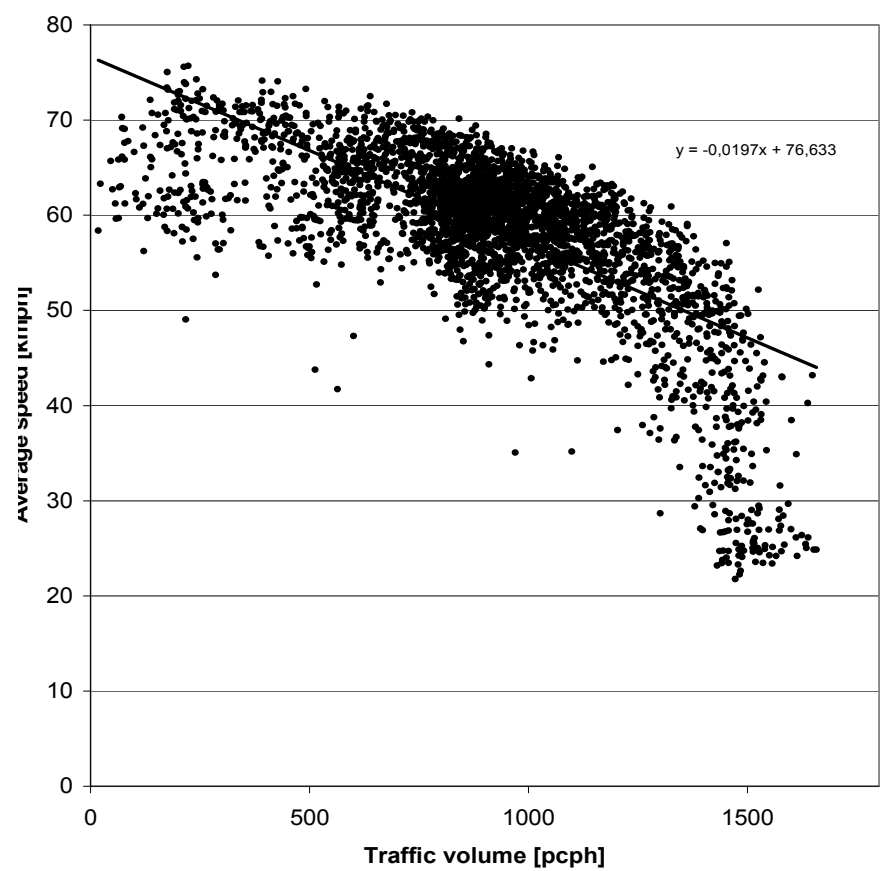

Fig. 3. $\mathrm{N}^{\circ} 1$ main road traffic volume-speed relation

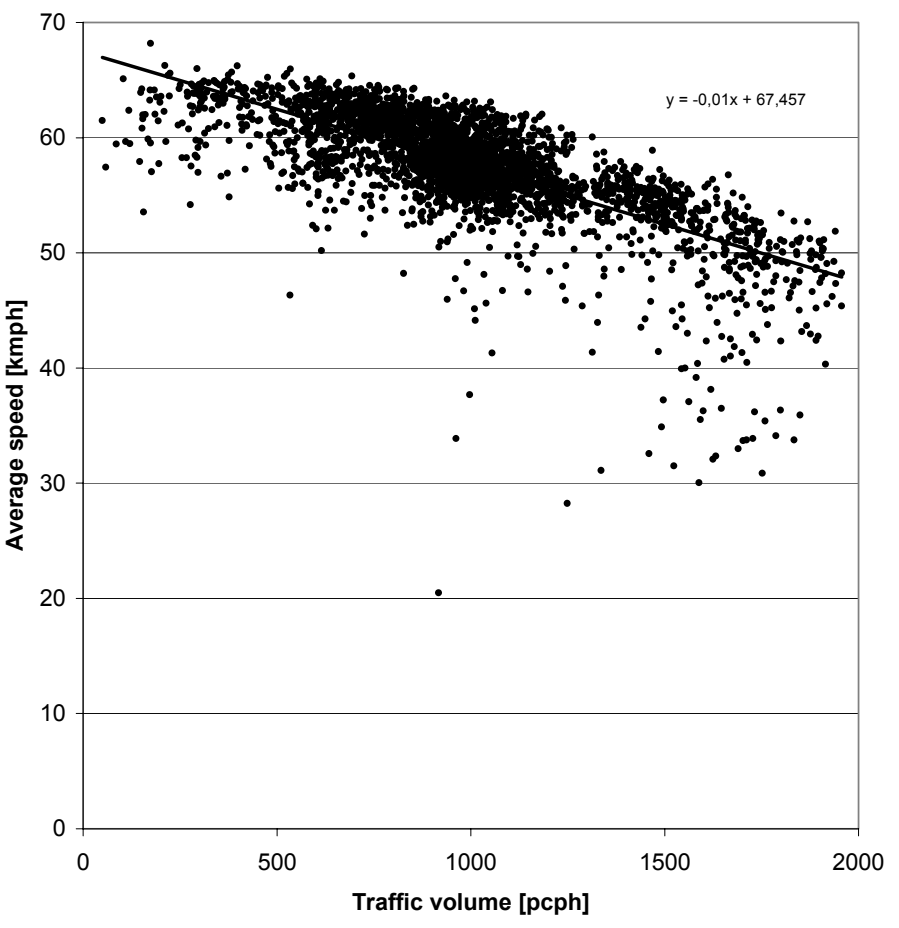

Fig. 4. $\mathrm{N}^{\circ} 1$ main road traffic volume-speed relation 
3987 - No.1 main road left lane (Györ)

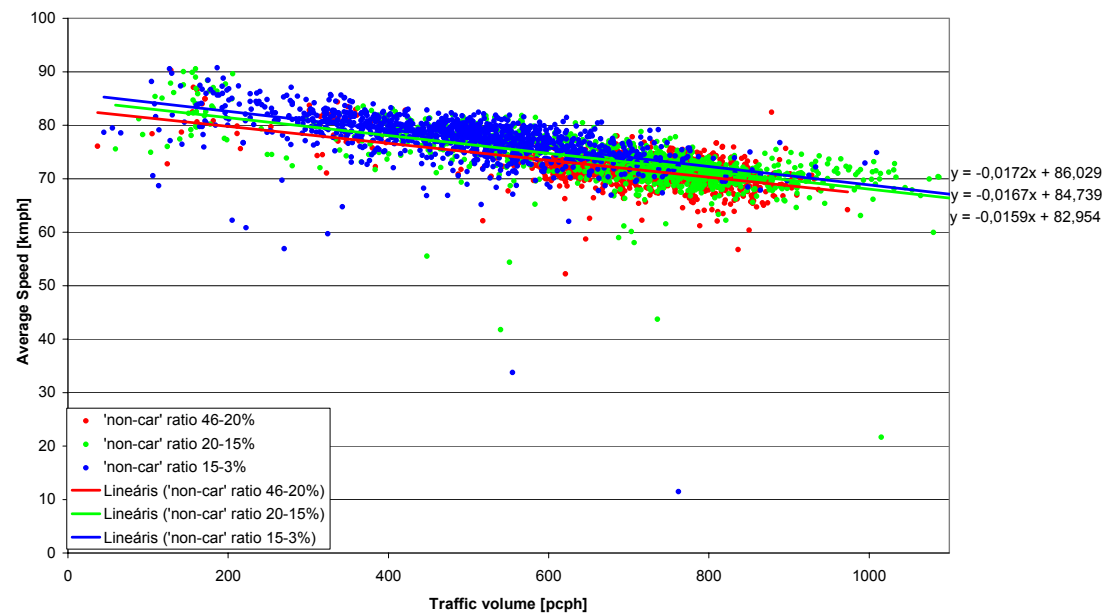

Fig. 5. Traffic volume - mean speed diagram in relation with traffic diversity $I^{s t}$

3247 - No.83 main road left lane (Györ)

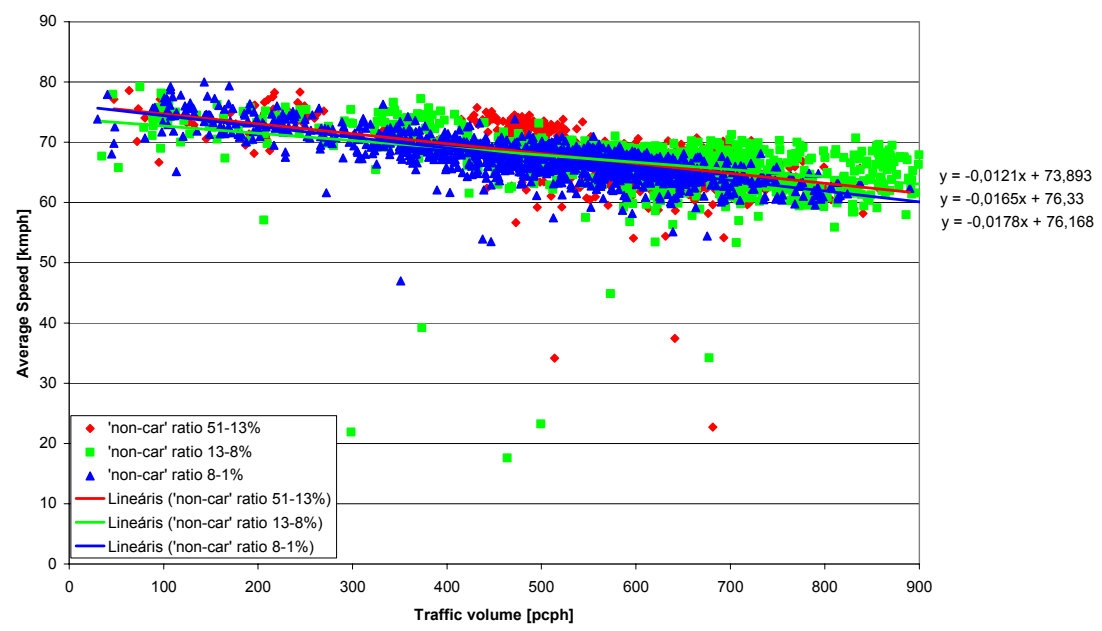

Fig. 6. Traffic volume - mean speed diagram in relation with traffic diversity $I I^{\text {nd }}$

3247 - No.83 main road left lane (Györ)

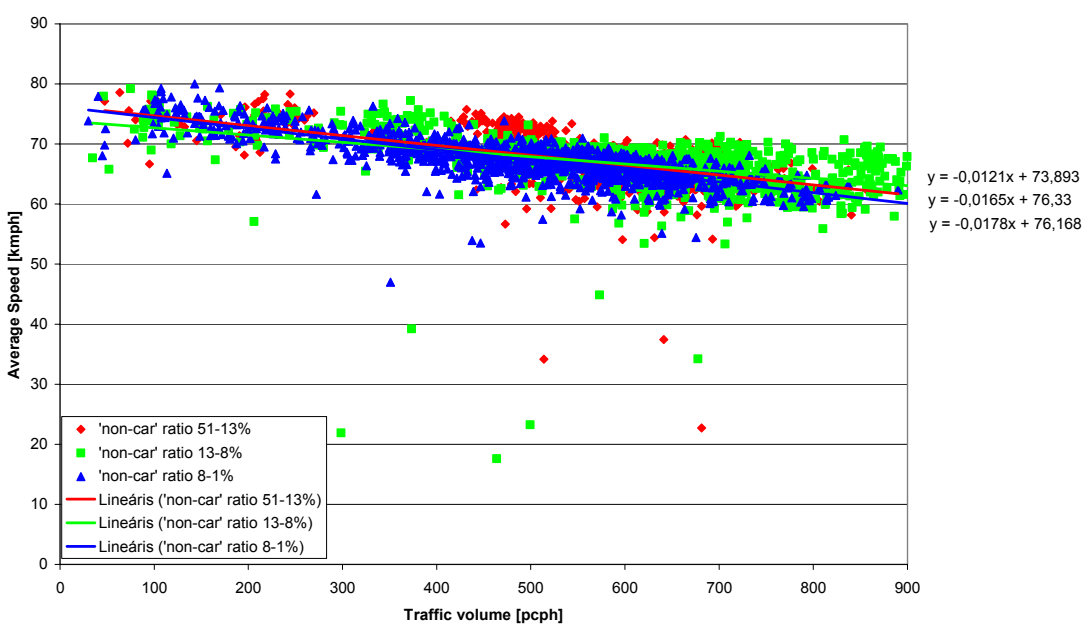

Fig. 7. Volume-speed relation of $\mathrm{N}^{\circ} 1$. main road 
Our earlier examinations have shown that the traffic mix - the ratio of ,non-cars”- has an effect on the free flow speed, and as a result of this on the traffic growth. To confirm this we made diagrams from the database of the two-lane roads. It categorizes the traffic volume of the given road into three categories according to the \% of ,non-car” occurrence on the road section. The three categories are mean high, middle and low ,non car” ratios of the hourly traffic. We represented the traffic volumemean speed value pairs in each category, than we suit regression straights on them. From the equation of the regression line the effect of traffic mix could be inferred.

During the examination we met with a case which confirmed this affirmation. Fig. 5. By the increase of ,non car” ratio only the free way speed decreases, the gradient of the line does not. During the examination we found also a contradictory case, when it was impossible to point out any logical relation between the traffic mix and the gradient and the direction of the regression line Fig. 6 .

\section{Conclusions and recommendations for the capacity value of two-lane roads}

The following two figures ( 7 and 8 ) are relevant in the determination of possible design volume of two-lane highways. Figures represent the traffic volumes/lanes (between 2007.05.01 and 2007.12.31 period of measurement) of $\mathrm{N}^{\circ} 1$ main road (which has optimal cross section construction). The heavy vehicle ratio is quite changeable. In the period of the highest traffic the ratio sets around $10-13 \%$ (the equivalent-factor according to the above mentioned is equal with 1,5).

If we think about the capacity as the traffic value just before the end of the decreasing speed-traffic volume function, that is to say the traffic volume before the evolving instable traffic it is seen that this value sets around $1700+1500$ pcphpl, or in another form 3200 pcph (in two directions).

It can be said that the statements of HCM 2000 for two-lane highways can also operate near Hungarian circumstances. Capacity values of the Hungarian regulations (Közutak Tervezése) failed much from the regular capacity values. The updating of these values is a national economy question, because the present capacity of the present network has an influence to the place and way of network development.

To follow from the above mentioned this type of determination of LOS, the HCM methodology could be used in Hungary. It is also recommended by us [5] and other authors [6-8].

Nevertheless it would be also important (while the approach of HCM comes into the practice of the traffic engineers) to characterize roads according to the ratio of traffic volume/capacity (v/C). By means of this all kind of traffic intervention can be justified obviously and the non efficient ones will be easily called in question.
1060 - No.1 main road left lane (Biatorbágy)

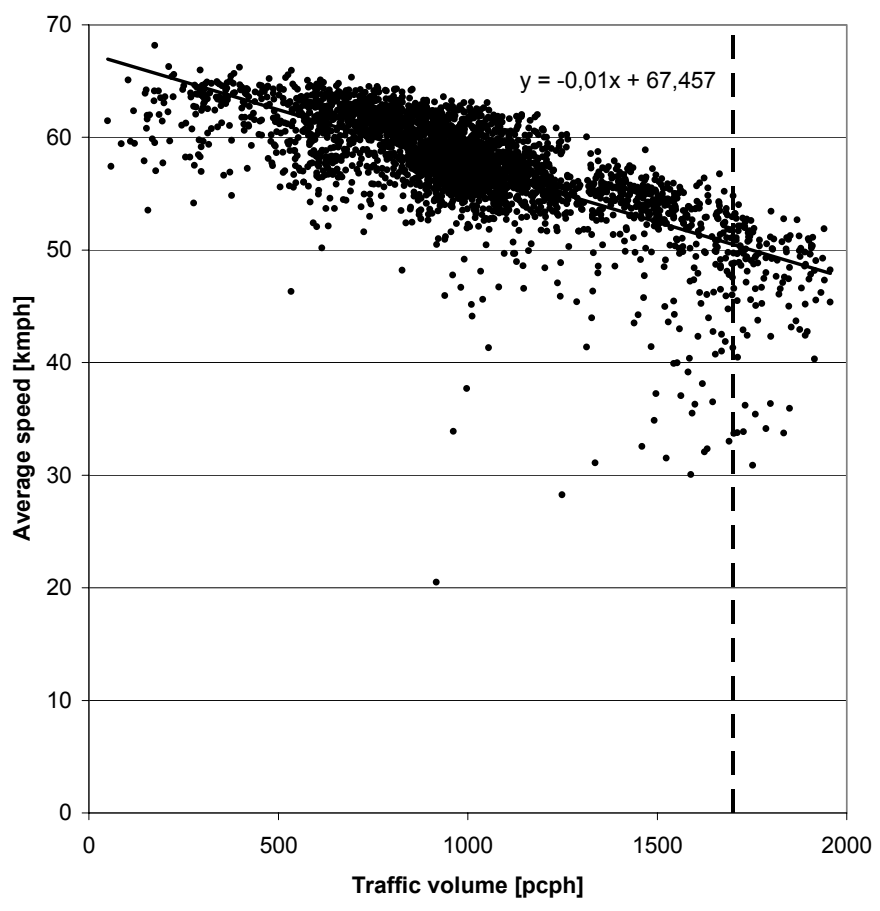

Fig. 8. Volume-speed relation of $\mathrm{N}^{\circ} 1$. main road

\section{References}

1 Highway Capacity Manual, Transportation Research Board National Research Council, Washington, D.C., 2000.

2 Road Planning, 2008.

3 Road Planning, 1986.

4 Tóth-Szabó Zs, The interpretations of the level of road service, Közúti és Mélyépítési Szemle 58, no. 7.

5 Galuska J, Fi I, Recommendation for new capacity values on freeways, Periodica Politechnica-Civil Engineering 54 (2010), no. 2, 127-136, DOI 10.3311/pp.ci.2010-2.08. http:/www.pp.bme.hu/ci.

6 Jankó D, Tóth-Szabó Zs, Kovács F, Szénási S, The determination of the level of road service by traffic measurements' data, Közúti és Mélyépítési Szemle 58, no. 8 .

7 Brilon W, Geistefeldt J, Zurlinden $\mathbf{H}$, Implementing the Concept of Reliability for Highway Capacity Analysis, Transportation Research Record: Journal of the Transportation Research Board, DOI 10.3141/2027-01, (to appear in print). http://trb.metapress.com/content/u700713ur834410r/.

8 Zegeer J, Blogg M, Nguyen K, Vandehey M, Default Values for Highway Capacity and Level-of-Service Analyses, Transportation Research Record: Journal of the Transportation Research Board, DOI 10.3141/2071-05, (to appear in print). http://trb.metapress.com/content/jwp3q53777416281/. 